\title{
Pemodelan Spasial Peak Ground Acceleration dan Prediksi Luas Genangan Tsunami di Kota Bengkulu
}

\author{
Dewi Susiloningtyas ${ }^{1^{*}}$, Della Ayu Lestari ${ }^{2^{*}}$, dan Supriatna ${ }^{1^{*}}$
}

IDepartemen Geografi, Fakultas Matematika dan Ilmu Pengetahuan Alam, Universitas Indonesia Margonda Raya, Depok, Indonesia

${ }^{\star}$ Email koresponden: dewi.susiloningtyas@sci.ui.ac.id

Direvisi: 2019-11-19 Diterima: 2020-8-25

(C)2020 Fakultas Geografi UGM dan Ikatan Geograf Indonesia (IGI)

\begin{abstract}
Abstrak Kota Bengkulu merupakan salah satu kota yang berada pada pesisir barat Pulau Sumatera yang mendapat pengaruh dari pertemuan Lempeng Indo-Australia dan Lempeng Eurasia serta Patahan Mentawai. Kondisi ini menyebabkan Kota Bengkulu rawan akan bencana gempa bumi dan tsunami. Tujuan penelitian ini adalah untuk mengetahui pola spasial kawasan rawan gempa bumi dan tsunami sebagai salah satu upaya mitigasi bencana. Kawasan rawan gempa bumi diamati dengan mencari Peak Ground Acceleration (PGA) gempa bumi di Kota Bengkulu pada tahun 2010 hingga 2018 sedangkan kawasan rawan tsunami diamati dengan mencari luas genangan tsunami dalam 3 skenario yaitu ketinggian gelombang 5 meter, 20 meter dan 25 meter dari garis pantai. Hasil penelitian menunjukkan bahwa wilayah terbangun eksiting yang memiliki resiko tertinggi berada bagian pesisir selatan Kota Bengkulu dengan wilayah PGA tinggi serta genangan tsunami yang luas dari tinggi gelombang tsunami 25 meter. Wilayah ini berada pada Kecamatan Kampung Melayu dengan prediski luas terdampak sebesar 653,69 Ha.
\end{abstract}

Kata kunci: gempa bumi, peak ground acceleration, tsunami, wilayah terbangun

\begin{abstract}
Bengkulu City is one of the cities on the west coast of Sumatra Island which has been influenced by the Indo-Australian Plate and the Eurasian Plate as well as the Mentawai Fault. This condition makes Bengkulu City prone to earthquakes and tsunamis. The purpose of this study is to determine the spatial pattern of earthquake and tsunami prone areas as one of the disaster mitigation efforts. Earthquake-prone areas were observed by looking for the Peak Ground Acceleration (PGA) of earthquakes in Bengkulu City from 2010 to 2018 while tsunamiprone areas were observed by looking for the area of tsunami inundation in 3 scenarios, namely the wave height of 5 meters, 20 meters and 25 meters from the coastline. The results showed that the highly developed area with the highest risk was the southern coast of Bengkulu City with a high PGA area and a large tsunami inundation from a tsunami wave height of 25 meters. This area is located in the Kampung Melayu subdistrict with a predisposition of an affected area of 653.69 hectares.
\end{abstract}

Keyword: built up area, earthquake, peak ground acceleration, tsunami

\section{PENDAHULUAN}

Indonesia dikenal sebagai negara yang memiliki kekayaan alam yang sangat berlimpah, salah satu kekayaan alamnya adalah di wilayah pesisir. Provinsi Bengkulu merupakan salah satu daerah pesisir yang secara geografis berada di sebelah barat pegunungan Bukit Barisan. Batas bagian barat wilayah Provinsi Bengkulu adalah Samudera Hindia dengan garis pantai sepanjang $525 \mathrm{~km}$ dengan sebagian besar penduduknya tinggal di wilayah pesisir tersebut terutama pada Kota Bengkulu (Cahyadinata et al., 2016). Namun Kota Bengkulu memiliki keterbatasan dalam dalam perkembangan kawasan permukiman karena berada pada wilayah rawan bencana gempa bumi dan tsunami (Pratami, 2018).

Kota Bengkulu merupakan salah satu wilayah di barat daya di Pulau Sumatera yang dipengaruhi oleh pertemuan Lempeng Indo-Australia dan Lempeng Eurasia. Wilayah ini juga dilewati oleh Patahan Sumatera (Patahan Semangko) dan mendapatkan juga pengaruh dari Patahan Mentawai. Patahan Mentawai berfungsi sebagai zona penahan (locking zone) terhadap desakan subduksi miring lempeng Australia di sebelah selatannya, dengan daya menahan mendekati $100 \%$ atau memiliki kemampuan menyimpan energi gempa yang tinggi (Natawidjaja, 2006).

Terdapat dua gempa yang menjadi bencana nasional di Provinsi Bengkulu dalam kurun waktu 16 tahun (tahun 2000 sampai dengan tahun 2017)). Berdasarkan data dari Badan Meteorologi Klimatologi dan Geofisika (BMKG) Provinsi Bengkulu, gempa yang pertama terjadi pada tanggal 4 Juni tahun 2000. Gempa ini mempunyai magnitudo 7,3 Skala Richter dengan kedalaman $33 \mathrm{~km}$ dan berada pada posisi VIII dalam Skala MMI (Supartoyo \& Surono, 2008). Kedua terjadi pada tanggal 12 September 2007 yang mempunyai magnitudo yang lebih tinggi dari sebelumnya yaitu sebesar 7,9 Skala Richter dengan kedalaman $30 \mathrm{~km}$ dan berada pada posisi IX dalam Skala Modified Mercalli Instensity (MMI). Gempa pada tahun 2007 ini juga menyebabkan tsunami dengan ketinggian 2,2 meter (Supartoyo \& Surono, 2008). .

Berdasarkan kondisi geografis Kota Bengkulu yang merupakan kawasan rawan bencana gempa dan tsunami, 
dengan pertumbuhan penduduk yang semakin berkembang maka lahan terbangun akan semakin berkembang pula, hal ini dapat meningkatkan risiko terhadap bencana gempa bumi dan tsunami sebagai bencana yang sulit diprediksi kedatangannya (Emad \& Sarah, 2016) . Kawasan rawan gempa bumi dianalisis berdasarkan nilai Peak Ground Acceleration (PGA) yang merupakan nilai percepatan getaran tanah terbesar yang pernah terjadi di suatu tempat yang diakibatkan oleh gelombang gempa bumi sehingga dapat menggambarkan resiko gempa bumi yang mungkin terjadi (Gandomi et al, 2016; Lestari et al, 2021). Penelitian tentang Peak Ground Acceleration sudah pernah dilakukan di Kota Bengkulu (Hadi et al, 2012), namun data yang digunakan terbatas pada kejadian gempa bumi yang terjadi di Kota Bengkulu. Sedangkan kerusakan yang besar yang terjadi di Kota Bengkulu disebabkan oleh gempa bumi di luar Kota Bengkulu. Sehingga pada penelitian ini menggunakan data gempa bumi yang lebih luas, yaitu Provinsi Bengkulu. Hal ini karena gempa bumi mengeluarkan energi gelombang yang akan menjalar ke segala arah sehingga meskipun titik gempa berada di luar Kota Bengkulu dengan adanya energi yang menjalar tersebut Kota Bengkulu akan tetap terkena dampak gempa bumi (Kumar et al, 2019).

Kota Bengkulu merupakan salah satu wilayah perairan di pesisir barat Pulau Sumatera yang terhubung langsung dengan perairan Samudera Hindia. Kota Bengkulu memiliki kondisi morfologi yang memungkinkan terjadinya mekanisme pengakumulasian gelombang air laut menuju daratan (Latief et al, 2000). Oleh karena itu kawasan rawan tsunami pada penelitian ini menggunakan pemodelan luas genangan tsunami yang mengacu pada skenario potensi gelombang maksimum dan waktu kedatangan gelombang tsunami yang telah di tetapkan pada Perka BNPB No. 2 tahun 2012. Penelitian terkait tsunami pernah dilakukan di Kota Bengkulu (Santinus, 2015) dengan menggunakan data penggunaan lahan Peta Rupa Bumi Indonesia skala 1:50.000 dan Citra SRTM untuk kemiringan lerengnya. Penelitian ini menggunakan data tutupan lahan dengan skala yang lebih detail yaitu Skala 1:10.000 tahun 2017 dan menggunakan Citra DEM dengan ketelitian yang jauh lebih detail dibandingkan Citra SRTM untuk kemiringan lereng. Dengan menggunakan data-data yang memiliki ketelitian yang lebih tinggi tersebut, penelitian ini dapat menggambarkan keadaan yang sebenarnya dengan lebih detail. Pemodelan spasial Peak Ground Acceleration dan prediksi luas genangan tsunami di Kota Bengkulu ini bertujuan sebagai salah satu upaya mitigasi bencana tsunami nonstruktural dapat dilakukan menggunakan sistem informasi geografis. Sistem informasi bencana gempa bumi dan tsunami diharapkan mampu memberikan himbauan kepada masyarakat untuk lebih paham mengenai potensi dan risiko bencana tsunami di tempat mereka tinggal (Lestari \& Sakti, 2020). Dengan demikian diharapkan masyarakat selalu waspada dan mampu menghindar saat bencana tiba sehingga dapat meminimalisasi korban jiwa.

\section{METODE PENELITIAN}

Kota Bengkulu merupakan ibukota Provinsi Bengkulu yang dibentuk berdasarkan Undang-Undang Darurat Nomor 6 Tahun 1956 tentang Pembentukan Daerah Otonom Kabupaten-Kabupaten dalam Lingkungan Daerah Propinsi Sumatera Selatan yang terdiri atas 9 kecamatan seperti pada Gambar 1. Penelitian ini menggunakan metode analisis kuantitatif dan analisis spasial dengan wilayah penelitian yang dikaji adalah Kota Bengkulu yang berdasarkan data wilayah rawan gempa bumi dan tsunami. Peta prediksi lahan terbangun dianalisis dengan kawasan rawan gempa bumi yaitu dari nilai Peak Ground Acceleration (PGA) maksimum yang menggambarkan efek gempa bumi paling parah yang pernah dialami pada masing-masing kelurahan (sebagai titik acuan) dan kawasan rawan tsunami dengan luas genangan tsunaminya. Gempa bumi yang dikaji dalam penelitian ini merupakan bencana gempa bumi tektonik dengan magnitudo $\geq 5,0$ Skala Richter dari Januari tahun 2000 hingga Agustus tahun 2018 dengan kedalaman kurang dari $100 \mathrm{~km}$ yang bersumber dari Badan Metorologi, dan Klimatologi dan Geofisika (BMKG) Provinsi Bengkulu dan United States Geological Survey (USGS). lahan terbangun dianalisis dengan kawasan rawan gempa bumi yaitu dari nilai Peak Ground Acceleration (PGA) maksimum yang menggambarkan efek gempa bumi paling parah yang pernah dialami pada masingmasing kelurahan (sebagai titik acuan) dan kawasan rawan tsunami dengan luas genangan tsunaminya. Gempa bumi yang dikaji dalam penelitian ini merupakan bencana gempa bumi tektonik dengan magnitudo $\geq 5,0$ Skala Richter dari Januari tahun 2000 hingga Agustus tahun 2018 dengan kedalaman kurang dari $100 \mathrm{~km}$ yang bersumber dari Badan Metorologi, dan Klimatologi dan Geofisika (BMKG) Provinsi Bengkulu dan United States Geological Survey (USGS).

Kawasan rawan tsunami dilakukan dengan pemodelan luas genangan tsunami berdasarkan Perka BNPB No. 2 tahun 2012. Pemodelan luas genangan tsunami dibagi menjadi 3 skenario berdasarkan (jurnal "A National Tsunami Hazard Assessment for Indonesia” oleh Horspool et al, 2013). Jurnal ini membagi prediksi ketinggian maksimum tsunami dalam 3 periode pada tiap provinsi di Indonesia, yaitu periode 100 tahun, periode 2.000 tahun dan periode 2.500 tahun. Untuk Kota Bengkulu pada periode 100 tahun, prediksi ketinggian maksimum tsunami dari garis pantai adalah setinggi 5 meter, pada periode 2.000 tahun setinggi 20 meter dan pada periode 2.500 tahun setinggi 25 meter. Data tutupan lahan didapatkan dari hasil digitasi Landsat 8 OLI dan Google Earth tahun 2017 dengan skala 1:10.000 dan data kemiringan lereng menggunakan data Digital Elevation Model (DEM) yang bersumber dari Badan Informasi Geospasial. Kemudian dilakukan teknik overlay dan analisis tabel silang untuk mengetahui wilayah yang paling rentan terhadap bencana gempa bumi dan seberapa luas lahan terbangun yang diprediksi akan terdampak (Gambar 2). Data yang digunakan untuk luas lahan terbangun yaitu menggunakan Citra Landsat 8 OLI/TIRS C1 Level-1 tanggal 22 Juni 2017 dengan teknik Supervised Classification dan metode Maximum Likelihood Classification dilakukan untuk memudahkan proses analisis. Klasifikasi terhadap citra dilakukan dengan menggunakan standar klasifikasi SNI 7645 - 2010 mengenai Klasifikasi Penutup Lahan.

Pengolahan data gempa bumi dalam penelitian ini adalah mencari nilai percepatan tanah maksimum atau Peak Ground Acceleration (PGA) yang menggunakan metode Gutenberg - Richter dengan formula Richter yang dikombinasi dengan formula attenuasi intensitas SubardjoPrih Harjadi yang merupakan fungsi dari magnitudo, jarak episenter, intensitas gempa bumi (Ibrahim, 2005). Dalam perhitungan nilai PGA dilakukan langkah-langkah sebagai berikut (Supriatna et al, 2010; Lestari et al, 2021): Menghitung jarak episenter Jarak episenter diketahui dengan 
menghitung jarak dari episenter ke titik $\mathrm{X}$, digunakan rumus: $\operatorname{Cos} \Delta=$ Cos Le Cos LX + Sin Le Sin LX Cos $(\lambda E-\lambda X)$ (Supriatna et al., 2010)

Keterangan :

Cos $\Delta$ : Jarak Episenter ke titik X

Lx : Lintang geografis titik X, yang akan dihitung nilai PGAnya;

$\lambda \mathrm{x}$ : Bujur geografis titik $\mathrm{X}$, yang akan dihitung nilai

PGAnya;

Le : Lintang geografis episenter,

$\lambda \mathrm{e}:$ Bujur geografis episenter

$\Delta \quad$ : Jarak antara titik $\mathrm{E}$ dan $\mathrm{X}$ dalam derajat

$\Delta^{\circ} \quad$ : dikonversikan ke dalam satuan kilometer dengan

mengalihkan $111,11 \mathrm{Km}$ untuk setiap $1^{\circ}$

Menghitung intensitas di hiposenter dengan rumus;

Io $=1,5(\mathrm{M}-0,5)$

(Richter tahun 1954 dalam Ibrahim, 2005)

Keterangan :

Io : Intensitas pada sumbernya;

M : Magnitudo dari gelombang badan / body wave (Skala Richter)

Menghitung intensitas di titik X dengan rumus konstanta atenuasi Prih Haryadi dan Subardjo:

$\mathrm{I}=($ Io . exp -b. $\Delta$ ) (Prih Haryadi dan Subardjo tahun 1992

dalam Ibrahim, 2005)

Keterangan :

I : Intensitas Permukaan

Io : Intensitas pada sumbernya

$\Delta$ : Jarak terhadap sumber gempa bumi (episenter)

$\mathrm{B}$ : Konstanta atenuasi (peluruhan energi), bernilai 0,0021

exp : Bilangan natural, bernilai 2,786

Menghitung nilai PGA di titik X dengan rumus;

$\log \alpha=(\mathrm{I} / 3)-0,5 \quad$ (Richter tahun 1954 dalam Ibrahim, 2005)

Keterangan :

a : Peak Ground Acceleration (PGA) dalam gal (cm/detik $\left.{ }^{2}\right)$

I : Intensitas permukaan dalam skala MMI dan angka 3 dan 0,5 adalah konstanta.

Titik gempa yang diambil dalam penelitian ini adalah gempa yang pernah terjadi di Provinsi Bengkulu dengan batas koordinat $2^{\circ} 16^{\prime} 36^{\prime \prime}$ LS hingga $5^{\circ} 26^{\prime} 32^{\prime \prime}$ LS dan $101^{\circ} 1^{\prime} 24^{\prime \prime}$ BT hingga $103^{\circ} 45^{\prime} 48^{\prime \prime}$ BT. Penentuan titik acuan dilakukan dengan pembuatan titik berat. Penentuan titik berat ini

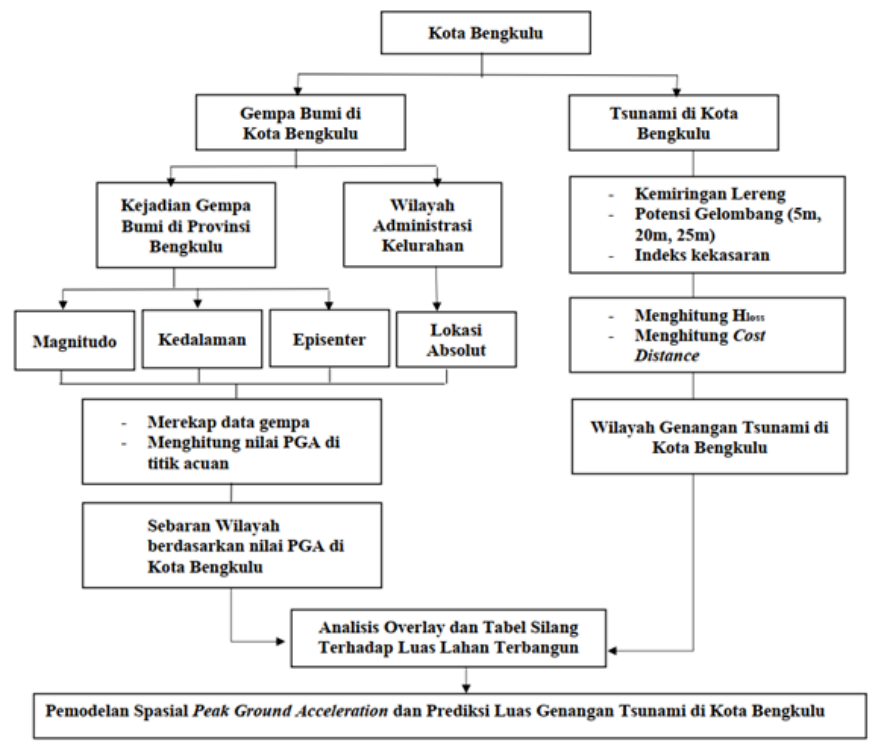

Gambar 2. Diagram Alir Penelitian dilakukan pada masing-masing kelurahan di Kota Bengkulu. Dalam satu kejadian gempa, dihitung nilai PGA nya di setiap titik berat sehingga di setiap titik didapatkan nilai PGA nya, lalu nilai PGA tersebut dihitung untuk seluruh titik acuan (Rahpeyma et al, 2019). Dari nilai-nilai PGA tersebut dicari nilai PGA maksimum disetiap titiknya. Semakin besar PGA yang terjadi di suatu tempat maka risiko bahayanya semakin besar. Tabel 1 menjelaskan tingkat resiko bencana berdasarkan nilai PGA dan Modified Mercalli Intensity (Skala MMI). Skala MMI terbagi ke dalam 12 kelas, masingmasing kategori mempunyai deskripsi yang berbeda tergantung bagaimana orang-orang dapat merasakan gempa dan seberapa besar kerusakan bangunan serta fasilitasfasilitas umum.

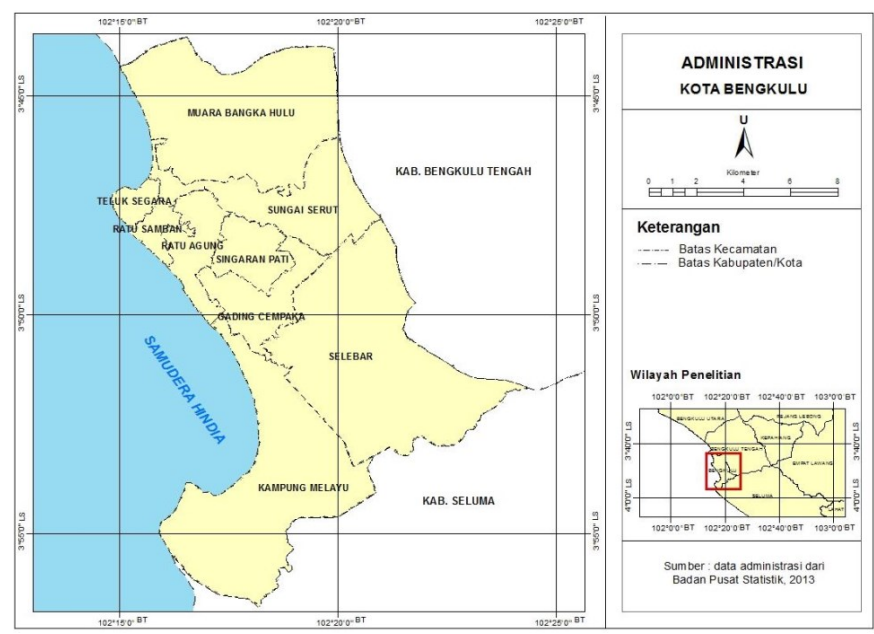

Gambar 1. Peta Lokasi Penelitian

Tabel 1. Tingkat Resiko Gempa Bumi

\begin{tabular}{lll}
\hline Tingkat Resiko & Nilai PGA (gals) & $\begin{array}{l}\text { Intensitas } \\
(\mathrm{MMI})\end{array}$ \\
\hline Resiko sangat kecil & $<25$ & $<$ VI \\
Resiko kecil & $25-50$ & VI-VII \\
Resiko sedang satu & $50-75$ & VII-VIII \\
Resiko sedang dua & $75-100$ & VII-VIII \\
Resiko sedang tiga & $100-125$ & VII-VIII \\
Resiko besar satu & $125-150$ & VIII-IX \\
Resiko besar dua & $150-200$ & VIII-IX \\
Resiko besar tiga & $200-300$ & VIII-IX \\
Resiko sangat besar satu & $300-600$ & IX-X \\
Resiko sangat besar dua & $>600$ & $>$ X \\
\hline
\end{tabular}

Untuk pemodelan wilayah rawan tsunami mengacu pada teknik pemodelan tsunami yang telah digunakan oleh BNPB dalam perhitungan matematis yang dikembangkan Berryman (2006) berdasarkan perhitungan kehilangan ketinggian tsunami per $1 \mathrm{~m}$ jarak ketinggian genangan berdasarkan nilai jarak terhadap lereng dan kekasaran permukaan. Pemodelan wilayah rawan tsunami ini menggunakan data kemiringan lereng, tutupan lahan, potensi gelombang maksimum tsuna$\mathrm{mi}$, dan garis pantai yang digunakan dalam perhitungan matematis sebagai berikut

$\left(\frac{167 n^{2}}{H_{0}^{1 / 8}}\right)+5 \operatorname{Sin} S H_{\text {loss }}=($ Berryman, 2006) 


\section{Dimana}

$\mathrm{H}_{\text {loss }}=$ kehilangan ketinggian tsunami per $1 \mathrm{~m}$ jarak ketinggian genangan

$\mathrm{N} \quad=$ indeks kekasaran permukaan

$\mathrm{H} 0=$ ketinggian gelombang tsunami di garis pantai $(\mathrm{m}$

$\mathrm{S} \quad=$ besarnya lereng permukaan (derajat)

Persamaan (5) menunjukkan perhitungan matematis yang dikembangkan Berryman (2006) berdasarkan perhitungan kehilangan ketinggian tsunami per $1 \mathrm{~m}$ jarak ketinggian genangan $\left(\mathrm{Hl}_{\text {oss }}\right)$. Dalam persamaan ini, dibutuhkan nilai nilai sin kemiringan lereng (SinS) sehingga nilai derajat dari lereng pelu dikonversi ke dalam radian. Konversi dilakukan dengan data kemiringan lereng dengan satuan derajat dikalikan dengan 0.01745 (hasil dari $\pi / 180$ ). N menunjukkan nilai indeks kekasaran permukaan yang didapatkan dari tutupan lahan (Tabel 2).

$\mathrm{H}_{0}$ menggambarkan potensi gelombang maksimum tsunami yang ditinjau berdasarkan Perka BNPB No. 2 Tahun 2012. Nilai $\mathrm{H}_{\text {loss }}$ diperlukan untuk perhitungan Cost Distance untuk wilayah keterpaparan dan zona aman evakuasi dengan dibatasi titik runup maksimum. Data garis pantai di-input

Tabel 2. Koefisien Kekasaran berdasarkan Jenis Tutupan Lahan (Sumber: Perka BNPB No. 2 Tahun 2012)

\begin{tabular}{ll}
\hline Jenis Tutupan lahan & $\begin{array}{l}\text { Indeks Kekasaran } \\
\text { Permukaan }\end{array}$ \\
\hline Badan Air & \\
Semak & 0,007 \\
Hutan & 0,040 \\
Perkebunan & 0,070 \\
Lahan Terbuka/Pasir/Jalan & 0,035 \\
Persawahan & 0,015 \\
Permukiman/Lahan & 0,025 \\
Terbangun & 0,045 \\
\hline
\end{tabular}

Sumber: Perka BNPB No. 2 Tahun 2012

sebagai batas awal pengukuran Cost Distance. Nilai Cost Distance tersebut berupa nilai cakupan gelombang tsunami mencapai titik run-up berdasarkan hasil $\mathrm{H}_{\text {loss. }}$. Wilayah keterpaparan didapatkan dari nilai potensi gelombang maksimum tsunami di Kota Bengkulu dikurangi dengan hasil Cost Distance. Nilai wilayah keterpaparan akan semakin berkurang ketika semakin menjauhi pantai.

\section{HASIL DAN PEMBAHASAN}

Frekuensi gempa bumi di Provinsi Bengkulu terbilang cukup tinggi, dalam kurun 16 tahun terakhir yaitu periode tahun 2000 hingga 2018 tercatat sebanyak 303 gempa bumi dengan kekuatan 5,0 Skala Richter hingga 7,9 Skala Richter serta dengan kedalaman kurang dari $100 \mathrm{~km}$. Gempa dengan kekuatan 5,0 Skala Richter hingga 5,9 Skala Richter terjadi sebanyak 283 kali, gempa dengan kekuatan 6,0 Skala Richter hingga 7,0 Skala Richter terjadi sebanyak 17 kali dan gempa dengan kekuatan diatas 7,0 Skala Richter terjadi sebanyak 2 kali dengan kekuatan magnitudo 7,3 Skala Richter dan 7,9 Skala Richter (Gambar 3).

\section{Peak Ground Acceleration (PGA) Gempa Bumi di Kota Bengkulu}

Sebaran wilayah PGA yang ada di Kota Bengkulu tertera pada Gambar 4 dengan nilai PGA terendah sebesar sebesar
376,14 gals dan nilai PGA tertinggi sebesar 506,90 gals. PGA dari data gempa bumi pada tanggal 12 September 2007 dengan kekuatan 7,9 Skala Richter memberikan pengaruh yang sangat berarti pada setiap kelurahan di Kota Bengkulu. Berdasarkan nilai PGA tersebut maka wilayah Kota Bengkulu berada pada risiko sangat besar satu atau kisaran IX dalam skala Modified Mercalli Intensity (MMI). Pada skala IX (MMI) identifikasi kejadian dapat berupa kerusakan pada bangunan yang kuat, rangka-rangka rumah menjadi tidak lurus, banyak retak, rumah tampak agak berpindah dari pondamennya, pipa-pipa dalam rumah putus.

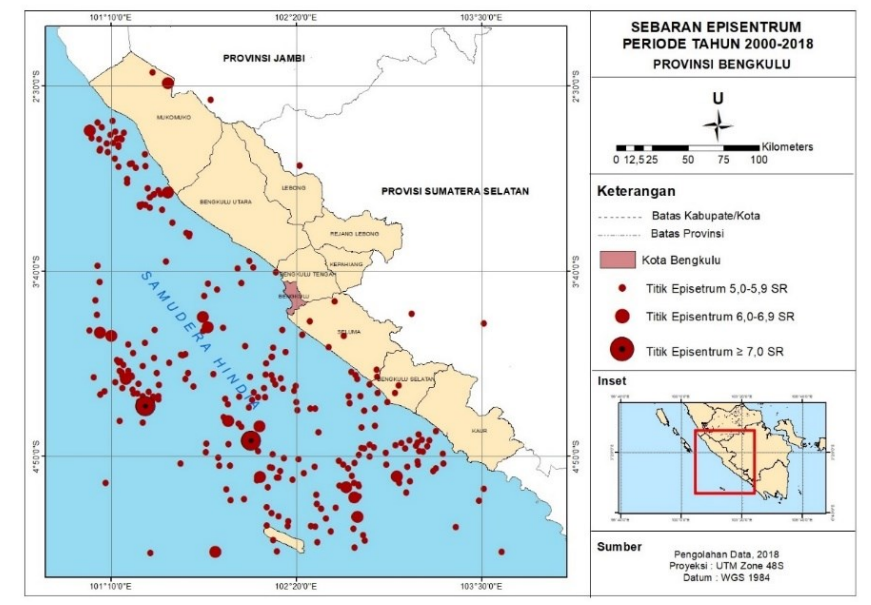

Gambar 3. Peta Sebaran Episentrum Periode Tahun 20002018 (Sumber: pengolahan data, 2018)

Berdasarkan Gambar 4 dengan menggunakan metode equal interval dapat diketahui sebaran PGA ini memiliki pola dengan PGA tertinggi di bagian selatan dan semakin ke utara nilai PGA semakin menurun. Wilayah PGA kelas rendah berada pada bagian utara Kota Bengkulu dengan nilai PGA < 412,32 gals. Kemudian wilayah PGA kelas sedang berada pada bagian sentral Kota Bengkulu dengan nilai PGA 412,32 - 451, 83 gals. Sedangkan wilayah PGA kelas tinggi berada pada selatan Kota Bengkulu dengan PGA > 451, 83 gals. Sehingga wilayah pada selatan Kota Bengkulu seperti Kecamatan Kampung Melayu dan sebagian Kecamatan Selebar mempunyai potensi risiko terhadap gempa bumi lebih besar dibandingkan dengan kecamatan lainnya meskipun seluruh kecamatan berada pada risiko sangat besar satu.

Lebih rincinya, Tabel 3 menjelaskan luas Peak Ground Acceleration (PGA) tiap Kecamatan di Kota Bengkulu. Berdasarkan Tabel 3 dapat diketahui untuk wilayah dengan PGA kelas rendah berada Kecamatan Muara Bangka Hulu dan Kecamatan Teluk Segara yang memenuhi seluruh luas kecamatannya sedangkan kecamatan Gading Cempaka berada pada PGA kelas sedang dan memenuhi seluruh luasan kecamatannya pula. Kecamatan dengan PGA kelas tinggi yang luas berada pada dua kecamatan, yaitu Kecamatan Selebar dan Kecamatan Kampung Melayu. Kecamatan Selebar mempunyai luas PGA kelas tinggi sebesar 2.362,00 Ha dan PGA kelas sedang seluas 2.762,23 Ha. Kecamatan Kampung Melayu memiliki luas PGA kelas tinggi terluas yaitu 4.043,86 Ha meskipun terdapat PGA kelas sedang di kecamatan ini dengan luas 292,83 Ha.

\section{Prediksi Wilayah Genangan Tsunami di Kota Bengkulu}

Dalam pengolahan data genangan tsunami, variabel kemiringan lereng didapatkan dari pengolahan DEM NAS 
0912-11, DEM NAS 0912-12, DEM NAS 0912-13, DEM NAS 0912-14 yang dihimpun dari Badan Informasi Geospasial, sedangkan indeks kekasaran permukaan didapatkan dari jenis klasifikasi tutupan lahan yang didigitasi dari Landsat 8 OLI dan Google Earth tahun 2017 dengan skala 1:10.000. Pada indeks tersebut ditunjukkan kombinasi aliran air yang mengalir di permukaan dengan topografi yang kasar seperti hutan dan semak, vegetasi pantai, bangunan-bangunan, topografi yang tidak teratur, sungai-sungai dan semua tutupan lahan di permukaan yang merupakan unsur yang sangat penting untuk mengetahui seberapa jauh genangan yang mungkin terjadi (Berryman 2006). Indeks kekasaran permukaan menentukan seberapa besar hambatan yang dimiliki setiap tutupan lahan. Semakin tinggi nilai indeks, maka tingkat kekasaran permukaan pada suatu klasifikasi tutupan lahan akan lebih tinggi (Damanik et al, 2018).

Prediksi Wilayah Genangan Tsunami dengan Tinggi Gelombang 5 meter

Setelah dilakukan pemodelan rayapan tsunami, didapatkan prediksi wilayah genangan tsunami atau potensi terjauh rayapan gelombang tsunami di sepanjang pesisir Kota Bengkulu yang dalam hal ini dengan asumsi tinggi gelombang 5 meter dari garis pantai. Secara keseluruhan, luas genangan tsunami dengan asumsi tinggi gelombang 5 meter adalah sebesar 2.628, $15 \mathrm{Ha}$ atau sebesar $14,06 \%$ dari luas Kota Bengkulu. Gambar 5 menunjukkan wilayah genangan tsunami relatif lebih luas pada bagian selatan Kota Bengkulu yaitu Kecamatan Kampung Melayu karena berdasarkan tutupan lahannya, bagian selatan ini mempunyai tutupan badan air dan lahan pertanian yang memiliki indeks kekasaran relatif rendah serta mempunyai lereng yang landai. Bagian barat laut Kota Bengkulu seperti pada Kecamatan Teluk Segara memiliki wilayah genangan tsunami terkecil, hal ini dikarenakan tutupan lahan Kecamatan Teluk Segara berupa lahan terbangun yang mempunyai indeks kekasaran cukup tinggi serta variasi kemiringan lereng yang cukup tinggi.

Berdasarkan Tabel 4 dapat diketahui luas genangan tsunami dengan tinggi gelombang 5 meter tiap kecamatan, kecamatan yang memiliki luas genangan terluas berada pada Kecamatan Kampung Melayu dengan luas genangan 1.873,99 $\mathrm{Ha}$ atau sebesar 43,21\% dari luas kecamatannya yaitu sebesar 4.336,69 Ha. Kecamatan dengan luas genangan tsunami terendah terdapat di Kecamatan Selebar yaitu hanya 0,02\% atau sebesar 1,08 Ha (luas kecamatan 5.123,23 Ha). Wilayah genangan ini berada pada bagian timur kecamatan yaitu adanya rayapan dari Kecamatan Gading Cempaka. Kecamatan yang sama sekali tidak terdampak pada tsunami ini adalah Kecamatan Singaran Pati karena secara spasial kecamatan ini terdapat di bagian sentral kota, sedangkan rayapan tsunami sudah habis di Kecamatan Ratu Agung dan Kecamatan Gading Cempaka yang mempunyai tutupan lahan terbangun dengan mempunyai indeks kekasaran cukup tinggi.

\section{Prediksi Wilayah Genangan Tsunami dengan Tinggi Ge- lombang 20 meter}

Secara keseluruhan, luas genangan tsunami dengan asumsi tinggi gelombang 20 meter mempunyai luas genagan lebih dari setengah luas Kota Bengkulu yaitu sebesar 10.470 Ha atau sebesar 56,82\% dari luas Kota Bengkulu. Gambar 6 menunjukkan wilayah genangan tsunami yang sudah menggenangi lebih dari setengah Kota Bengkulu, titik terjauh genangan berada terutama pada bagian utara yaitu pada Kecamatan Muara Bangka Hulu, bagian sentral Kota Bengkulu yaitu pada Kecamatan Selebar dan bagian selatan pada Kecaman Kampung Melayu.

Berdasarkan Tabel 5 dapat diketahui luas genangan tsunami dengan tinggi gelombang 20 meter tiap kecamatan. Kecamatan yang berada pada bagian barat dan selatan Kota Bengkulu serta berhadapan langsung dengan garis pantai habis oleh genangan tsunami Kecamatan Teluk Segara, Kecamatan Ratu Agung, Kecamatan Ratu Samban dan

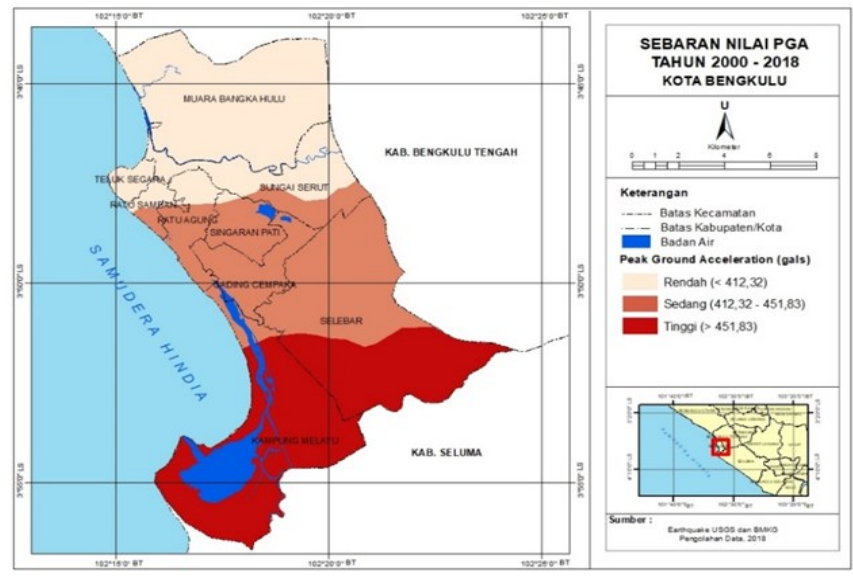

Gambar 4. Peta Sebaran Nilai PGA Tahun 2000 - 2018 di Kota Bengkulu (Sumber: pengolahan data, 2018)

Tabel 3. Luas Peak Ground Acceleration (PGA) Tiap Kecamatan di Kota Bengkulu (Sumber: pengolahan data, 2018)

\begin{tabular}{|c|c|c|c|c|}
\hline \multirow{2}{*}{ Nama Kecamatan } & \multicolumn{3}{|c|}{ Luas Peak Ground Acceleration (Ha) } & \multirow{2}{*}{ Luas Kecamatan (Ha) } \\
\hline & Rendah & Sedang & Tinggi & \\
\hline Gading Cempaka & 0,00 & $1.042,79$ & 0,00 & $1.042,79$ \\
\hline Kampung Melayu & 0,00 & 292,83 & $4.043,86$ & $4.336,69$ \\
\hline Muara Bangkahulu & $4.219,66$ & 0,00 & 0,00 & $4.219,66$ \\
\hline Ratu Agung & 278,18 & 534,82 & 0,00 & 812,99 \\
\hline Ratu Samban & 195,63 & 122,12 & 0,00 & 317,74 \\
\hline Selebar & 0,00 & $2.762,23$ & $2.362,00$ & $5.123,23$ \\
\hline Singaran Pati & 39,99 & 695,29 & 0,00 & 735,28 \\
\hline Sungai Serut & $1.328,02$ & 509,91 & 0,00 & $1.839,92$ \\
\hline Teluk Segara & 263,17 & 0,00 & 0,00 & 263,17 \\
\hline
\end{tabular}


Kecamatan Kampung Melayu. Kecamatan dengan persentase luas genangan yang tinggi terdapat pada Kecamatan Gading Cempaka yaitu mempunyai luas genangan sebesar 668,30 Ha atau sebesar 64,09\% dari luas kecamatannya sebesar 1.042,79 Ha. Persentase luas genangan terendah berada pada Kecamatan Selebar karena secara spasial kecamatan ini terdapat di bagian timur kota yang cukup jauh dari garis pantai serta rayapan tsunami sudah banyak habis di Kecamatan Kampung Melayu, Kecamatan Gading Cempaka, Kecamatan Singaran Pati dan Kecamatan Sungai Serut. Oleh karena itu Kecamatan Selebar hanya tergenang sebesar $11,50 \%$ atau

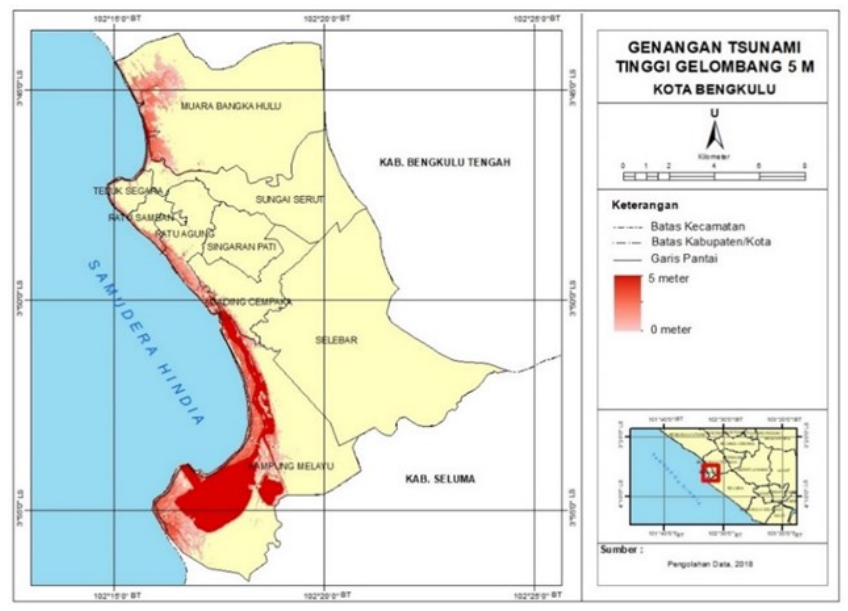

Gambar 5. Prediksi Wilayah Genangan Tsunami dengan Tinggi Gelombang 5 meter (Sumber: pengolahan data, 2018) sebesar 589,19 dibandingkan dengan luas kecamatannya sebesar 5.123,23 Ha.

Prediksi Wilayah Genangan Tsunami dengan Tinggi Gelombang 25 meter

Secara keseluruhan, luas genangan tsunami dengan tinggi gelombang 25 meter mempunyai luas genangan yang luas yaitu sebesar 12.210,62 Ha atau sebesar 71,21\% dari luas Kota Bengkulu. Gambar 7 menunjukkan wilayah genangan tsunami yang sudah menggenangi hampir seluruh Kota Bengkulu kecuali pada bagian tenggara dan timur, titik

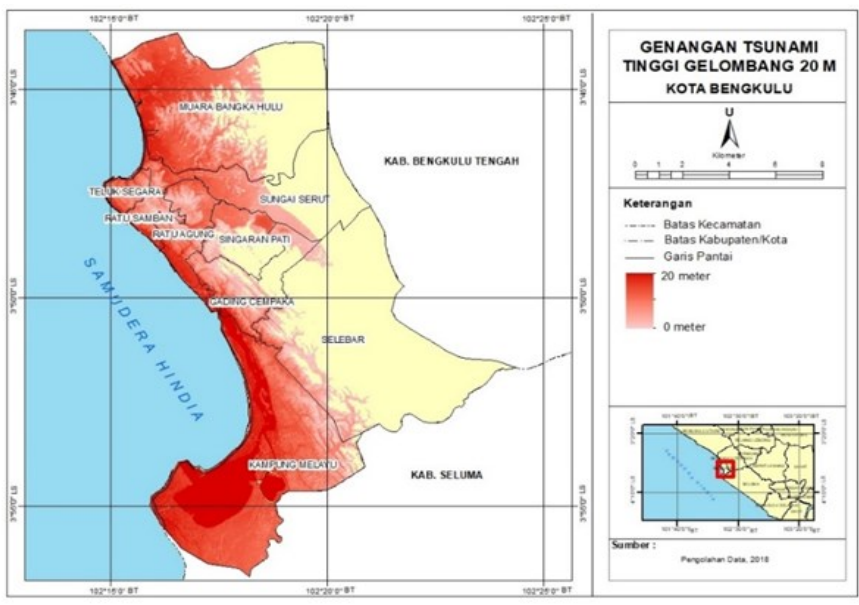

Gambar 6. Prediksi Wilayah Genangan Tsunami dengan Tinggi Gelombang 20 meter (Sumber: pengolahan data, 2018)

Tabel 4. Prediksi Luas Genangan Tsunami dengan Tinggi Gelombang 5 meter Tiap Kecamatan di Kota Bengkulu (Sumber: pengolahan data, 2018)

\begin{tabular}{lrrr}
\hline \multicolumn{1}{c}{ Nama Kecamatan } & Luas Genangan (Ha) & Luas Kecamatan (Ha) & Persentase (\%) \\
\hline Gading Cempaka & 45,21 & $1.042,79$ & 4,34 \\
Kampung Melayu & $1.873,99$ & $4.336,69$ & 43,21 \\
Muara Bangkahulu & 434,74 & $4.219,66$ & 10,30 \\
Ratu Agung & 138,26 & 812,99 & 17,01 \\
Ratu Samban & 39,50 & 317,74 & 12,43 \\
Selebar & 1,08 & $5.123,23$ & 0,02 \\
Singaran Pati & 0,00 & 735,28 & 0,00 \\
Sungai Serut & 47,30 & $1.839,92$ & 2,57 \\
Teluk Segara & 48,07 & 263,17 & 18,27 \\
\hline
\end{tabular}

Tabel 5. Prediksi Luas Genangan Tsunami dengan Tinggi Gelombang 20 meter Tiap Kecamatan di Kota Bengkulu (Sumber: pengolahan data, 2018)

\begin{tabular}{lrrr}
\hline \multicolumn{1}{c}{ Nama Kecamatan } & Luas Genangan (Ha) & Luas Kecamatan (Ha) & Persentase (\%) \\
\hline Gading Cempaka & 668,30 & $1.042,79$ & 64,09 \\
Kampung Melayu & $4.336,69$ & $4.336,69$ & 100,00 \\
Muara Bangka Hulu & $2.397,36$ & $4.219,66$ & 56,81 \\
Ratu Agung & 812,99 & 812,99 & 100,00 \\
Ratu Samban & 317,74 & 317,74 & 100,00 \\
Selebar & 589,19 & $5.123,23$ & 11,50 \\
Singaran Pati & 353,70 & 735,28 & 48,10 \\
Sungai Serut & 731,33 & $1.839,92$ & 39,75 \\
Teluk Segara & 263,17 & 263,17 & 100,00 \\
\hline
\end{tabular}




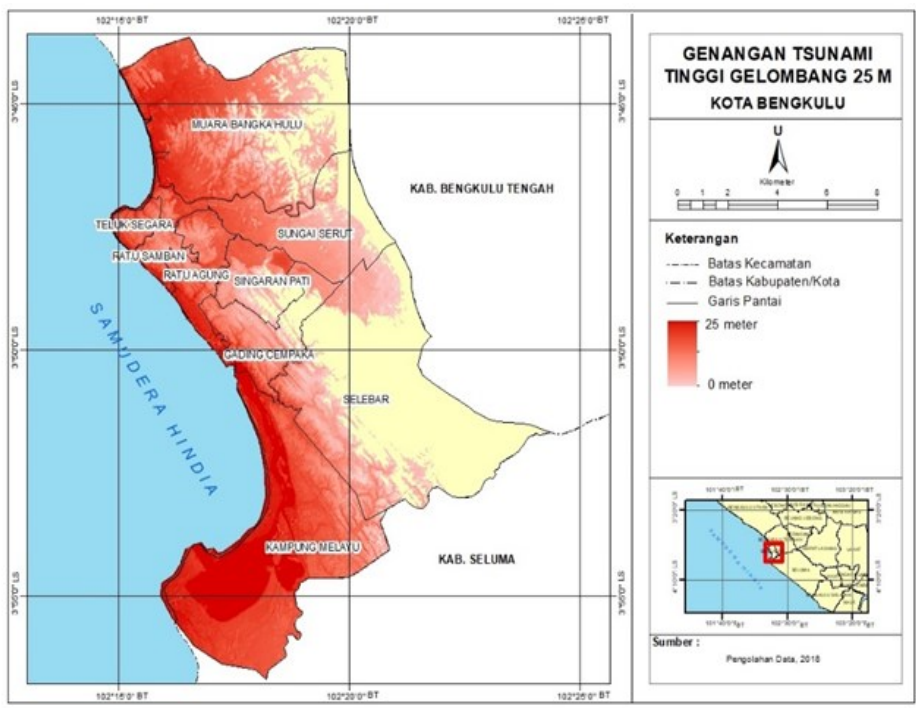

Gambar 7. Prediksi Wilayah Genangan Tsunami dengan Tinggi Gelombang 25 meter (Sumber: pengolahan data, 2018)

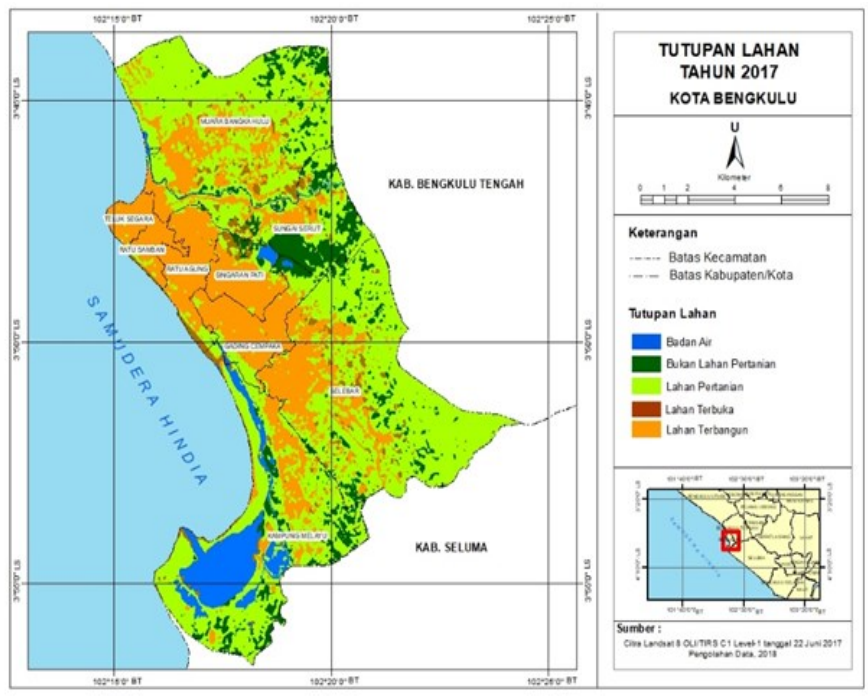

Gambar 8. Peta Tutupan Lahan Kota Bengkulu Tahun 2017 (Sumber: pengolahan data, 2018)

Tabel 6. Prediksi Luas Genangan Tsunami dengan Tinggi Gelombang 25 meter Tiap Kecamatan di Kota Bengkulu (Sumber: pengolahan data, 2018)

\begin{tabular}{lrrr}
\hline \multicolumn{1}{c}{ Nama Kecamatan } & Luas Genangan (Ha) & Luas Kecamatan (Ha) & Persentase (\%) \\
\hline Gading Cempaka & 853,77 & $1.042,79$ & 81,87 \\
Kampung Melayu & $4.336,69$ & $4.336,69$ & 100,00 \\
Muara Bangka Hulu & $3.220,56$ & $4.219,66$ & 76,32 \\
Ratu Agung & 812,99 & 812,99 & 100,00 \\
Ratu Samban & 317,74 & 317,74 & 100,00 \\
Selebar & $1.570,72$ & $5.123,23$ & 30,66 \\
Singaran Pati & 539,55 & 735,28 & 73,38 \\
Sungai Serut & $1.395,43$ & $1.839,92$ & 75,84 \\
Teluk Segara & 263,17 & 263,17 & 100,00 \\
\hline
\end{tabular}

terjauh genangan berada terutama pada bagian tenggara Kota Bengkulu yang berada pada Kecamatan Selebar. Berdasarkan Tabel 6 dapat diketahui luas genangan tsunami dengan tinggi gelombang 25 meter tiap kecamatan. Kecamatan yang berada pada bagian barat dan selatan Kota Bengkulu serta berhadapan langsung dengan garis pantai habis oleh genangan tsunami Kecamatan Teluk Segara, Kecamatan Ratu Agung, Kecamatan Ratu Samban dan Kecamatan Kampung Melayu. Kecamatan dengan persentase luas genangan yang tinggi terdapat pada Kecamatan Gading Cempaka yaitu mempunyai luas genangan sebesar $853.77 \mathrm{Ha}$ atau sebesar $81,87 \%$ dari luas kecamatannya sebesar $1.042,79$ Ha. Sama dengan pada tinggi gelobang 20 meter, persentase luas genangan terendah pada tinggi gelombang 25 meter ini juga berada pada Kecamatan Selebar karena secara spasial kecamatan ini terdapat di bagian timur kota yang cukup jauh dari garis pantai serta rayapan tsunami sudah banyak habis di Kecamatan Kampung Melayu, Kecamatan Gading Cempaka, Kecamatan Singaran Pati dan Kecamatan Sungai Serut serta kecamatan ini mempunyai kemiringan lereng yang cukup tinggi pula. Sehingga itu Kecamatan Selebar hanya tergenang sebesar $30,66 \%$ atau sebesar $1.570,72 \mathrm{Ha}$ dibandingkan dengan luas kecamatannya sebesar 5.123,23 Ha.
Luas Lahan Terbangun terhadap Wilayah Peak Ground Acceleration (PGA) dan Wilayah Genangan Tsunami di Kota Bengkulu

Lahan terbangun terdiri dari lahan terbangun, permukiman, jaringan jalan, bandar udara dan pelabuhan laut. Hasil analisis tersebut menunjukkan pada tahun 2017 tutupan lahan masih di dominasi oleh tutupan lahan pertanian yaitu seluas 9801,40 Ha dan yang luas terkecil berada pada tutupan lahan berupa lahan terbuka yaitu hanya seluas 687,06 Ha sedangkan untuk luas lahan terbangun pada tahun ini sebesar 5.306,31 Ha (Gambar 8).

Tabel 7 merupakan tabel silang antara luas lahan terbangun pada tahun 2017 terhadap wilayah rawan gempa dan tsunami di Kota Bengkulu, luas lahan terbangun pada wilayah PGA kelas rendah dan wilayah genangan tsunami dengan ketinggian 25 meter selalu lebih luas dibandingkan dengan kelas PGA atau tsunami lainnya yaitu pada tahun tahun 2017 sebesar 1.692,81 Ha. Secara spasial wilayah ini terdapat pada utara Kota Bengkulu yang mendapatkan desakan penduduk dari bagian barat laut dan sentral Kota Bengkulu seperti pada Kecamatan Singaran Pati, Kecamatan Gading Cempaka dan sebagian Kecamatan Ratu Agung, Kecamatan Ratu Samban. Penduduk berkembang ke bagian 
Tabel 7. Tabel Silang Luas Lahan Terbangun pada Wilayah Gempa Bumi dan Tsunami di Kota Bengkulu (Sumber: pengolahan data, 2018)

\begin{tabular}{ccrrr}
\hline \multirow{2}{*}{ Tahun } & Luas Lahan Terbangun pada & \multicolumn{3}{c}{ Luas Lahan terbangun pada Wilayah Genangan } \\
Wilayah PGA (Ha) & \multicolumn{3}{c}{ Tsunami (Ha) } \\
\cline { 3 - 5 } & & $5 \mathrm{~m}$ & \multicolumn{1}{c}{$20 \mathrm{~m}$} & \multicolumn{1}{c}{$25 \mathrm{~m}$} \\
\hline \multirow{3}{*}{2017} & Rendah & 93,43 & $1.407,85$ & $1.692,81$ \\
& Sedang & 139,05 & $1.249,20$ & $1.770,74$ \\
& Tinggi & 30,75 & 550,39 & 653,69 \\
\hline
\end{tabular}

utara Kota Bengkulu ini karena sesuai dengan faktor fisik dan faktor aksesibilitas yang cukup memadai sehingga wilayah ini mempunyai wilayah sesuai dan kurang sesuai untuk lahan terbangun. Dengan tutupan lahan yang umumnya berupa lahan terbangun serta lahan pertanian dengan indeks kekasaran rendah cenderung sedang, ditambah dengan variasi kemiringan lereng yang cukup landai maka wilayah genangan tsunami pada wilayah ini cukup luas. Wilayah yang paling berpotensi mendapatkan dampak terjadinya gempa bumi dan tsunami dalam analisis ini adalah lahan terbangun yang berada pada wilayah PGA kelas tinggi dan berada pada genangan tsunami dengan ketinggian 25 meter dari garis pantai yaitu seluas 653,69 $\mathrm{Ha}$.

\section{KESIMPULAN}

Letak geografis Kota Bengkulu yang berada pertemuan Lempeng Indo-Australia dan Lempeng Eurasia serta Patahan Mentawai sehingga menjadikan wilayah ini rawan akan bencana gempa bumi dan tsunami. Berdasarkan pengolahan data, sebaran Peak Ground Acceleration (PGA) terendah berada pada utara Kota Bengkulu dengan nilai PGA kurang dari 412,32 gals dan tertinggi pada wilayah selatan Kota Bengkulu dengan PGA lebih dari 451,83 gals. Kemudian berdasarkan analisis terhadap wilayah genangan tsunami dengan 3 skenario, tsunami dengan tinggi gelombang 25 meter memiliki resiko yang tinggi dengan luas genangan sebesar 12.210,62 $\mathrm{Ha}$ atau sebesar $71,21 \%$ dari luas Kota Bengkulu yang menggenangi hampir seluruh Kota Bengkulu kecuali pada bagian tenggara dan timur. Wilayah lahan terbangun yang PGA tinggi dengan prediksi genangan tsunami terluas (tinggi gelombang $25 \mathrm{~m}$ ) memiliki resiko tertinggi terhadap bencana yaitu seluas 653, $69 \mathrm{Ha}$. Wilayah ini secara spasial terdapat pada bagian pesisir selatan Kota Bengkulu sehingga wilayah bagian ini perlu mendapat perhatian khusus dalam mitigasi bencana. Dibutuhkan cara untuk mengurangi potensi dampak jika terjadi gempa bumi dan tsunami diminimalisir dengan meningkatkan indikator kapasitas adaptifnya.

\section{UCAPAN TERIMA KASIH}

Terima kasih kepada Badan Perencanaan Pembangunan Daerah (BAPPEDA) Kota Bengkulu, Badan Meterologi Klimatologi dan Geofisika (BMKG) Provinsi Bengkulu dan Badan Penanggulangan Bencana Daerah (BNPB) Provinsi Bengkulu atas bantuan data yang diberikan.

\section{KONTRIBUSI PENULIS}

Penulis ke-1: menyusun kerangka penelitian dan metodelogi, melakukan pencarian daftar rujukan dan mem- buat naskah publikasi. Penulis ke-2: menyusun model, menjalankan model, melakukan pencarian daftar rujukan dan membuat naskah publikasi. Penulis ke-3 melakukan evaluasi model.

\section{DAFTAR PUSTAKA}

Badan Informasi Geospasial. (2018, 1 Agustus). DEMNAS Seamless Digital Elevation Model (DEM) dan Batimetri Nasional. Diakses tanggal 1 Agustus dari 2018 dari http://tides.big.go.id/ DEMNAS/DEMNAS.php

Badan Meteorologi Klimatologi dan Geofisika Nasional. (2018, 1 Agustus). Gempabumi. Diakses tanggal 1 Agustus dari 2018 dari http://www.bmkg.go.id/bmkg

Berryman, Kelvin. (2006). Review of Tsunami hazard and risk in New Zealand. New Zealand: Institute of Geological and Nuclear Sciences, pp. 64.

Cahayadinata I \& Arianti, N.N. (2016). Kajian Dampak Pemekaran Wilayah terhadap Kesenjangan Ekonomi Antar Daerah Pesisir di Provinsi Bengkulu. Jurnal Agrisep Universitas Bengkulu

Damanik, M. R. S., Nurman A, Restu, R., \& Berutu,N. (2018). Tsunami Risk Analysis With Run-up Variation Scenario Based On Modeling Of Geographic Information System On Sibolga City North Sumatera. Int. J. Eng. Technol.

Emad G.S.M. \& Sarah L.G. (2016). Application of GMPEs to Estimate the Minimum Magnitude and Peak Ground Acceleration of Prehistoric Earthquakes at Hollywood, Journal of Engineering Geology, vol.214,1 pp.60-66

Fauzi, et al. (2016). Geographic Information System for Natural Disater Map in Indonesia.

Gandomi M., Soltanpour M., Zolfaghari M.R., \& Gandomi A.H. (2016). Prediction of Peak Ground Acceleration of Iran's Tectonic Regions Using a Hybrid Soft Computing Technique, Journal of Geoscience Frontiers, vol.7, pp.75-82

Hadi, A.I., Farid. M., \& Fauzi. (2012). Pemetaan Percepatan Getaran Tanah Maksimum dan Kerentanan Seismik Akibat Gempa Bumi untuk Mendukung Rencana Tata Ruang dan Wilayah (RTRW) Kota Bengkulu. SIMETRI, Jurnal Ilmu Fisika Indonesia vol. 1, no.2, pp. 82-86.

Horspool, N., Griffin, J., Pranantyo, I. R., Latief, H., Natawidjaja, D., Kongko, W., Cipta, A., Bustaman, A., Suci D. \& Hong K.T.. (2013). A National Hazard Assesment for Indonesia. Commonwealth of Australia

Ibrahim, G \& Subardjo. (2005). Pengetahuan Seismologi. Jakarta: Badan Meteorologi dan Geofisika

Kumar P., Chamoli B.P., Kumar A., \& Gairola A. (2019). Attenuation relationship for peak horizontal acceleration of strong ground motion of Uttarakhand region of central Himalayas. Journal of Earthquake Engineering, 2019, pp.1-18

Latief, Hamzah., Puspito, Nanang \& Rumuhiko Imamura. (2000). Tsunami Catalog and Zones in Indonesia. Journal of Natural Disaster Science, Vol.22, Number 1, pp .5-43

Lestari, D.A \& Sakti, B. (2020). Social Vulnerability to Earthquake Hazard at Pringsewu District, Lampung Province. IOP Conference Series: Earth and Environmental Science 561 (1), 012046

Lestari, D.A., Susiloningtyas, D., Hartanto, M., Ahmad, T.E., 
Azhari, D.R. \& Rais, A. (2021). Spatial Patterns of Peak Ground Acceleration (PGA) Earthquake on Final Disposal Sites Plan in Samosir Regency. IOP Conference Series: Materials Science and Engineering, vol. 1062, no.1, 2021, doi: doi:10.1088/1757899X/1062/1/012010

Natawidjaja, D.H. (2006). Gempabumi dan Tsunami di Sumatra dan Upaya Untuk Mengembangkan Lingkungan Hidup Yang Aman dari Bencana Alam. Jakarta: Lembaga Ilmu Pengetahuan (LIPI)

Perka BNPB No. 2 Tahun 2012 tentang Pedoman Umum Pengkajian Risiko Bencana. Badan Nasional Penanggulangan Bencana

Pratami, Mentari. (2018). Pemodelan Cellular Automata untuk Daya Dukung Lahan Permukiman di Kota Bengkulu. Depok: Tesis Departemen Geografi, FMIPA, Universitas Indonesia.

Rahpeyma S., Halldorsson B., Hranskelsson B., Green R.A., \& Jonsson S. (2019). Site Effect Estimation on Two1 Icelandic Strong-Motion Arrays Using a Bayesian Hierarchical Model for the Spatial Distribution of1 Earthquake Peak Ground Acceleration, Journal of Soil Dynamics and Earthquake Engineering, vol.120, 1 pp.369-385
Santius, S.H. (2015). Pemodelan Tingkat Risiko Bencana Tsunami Pada Permukiman Di Kota Bengkulu Menggunakan Sistem Informasi Geografis. Jurnal Permukiman Vol. 10 No. 2. Hal.: 92-105

Supartoyo \& Surono. (2008). Katalog Gempa Bumi Merusak di Indonesia tahun 1629-2007. Departemen Energi dan Sumber Daya Mineral, Badan Geologi Pusat Vulkanologi dan Mitigasi Bencana Geologi

Supriatna, Samedi, J.M., \& Nurmala, C. (2010). Peak Ground Acceleration (PGA) of Destructive Earthquake in Cimandiri Fault, Sukabumi, West Java. Paper Reference Number 17. Depok: Department of Geography, Faculty of Mathemathic and Natural Science University of Indonesia

United States Geological Survey. (2018, 14 Juni). Earthquake Hazard Program. Diakses tanggal 14 Juni 2018 dari https://earthquake.usgs.gov/ 